\author{
L.M. Ushakova, E.M. Demianenko, M.I. Terets, V.V. Lobanov, N.T. Kartel
}

\title{
Interaction of N-Acetylneyraminic Acid with Surface of Silica with Fructose in Aqueous Solution
}

\author{
Chuiko Institute of Surface Chemistry, NAS of Ukraine, Kyiv, Ukraine, milushakova@ gmail.com
}

\begin{abstract}
Quantum chemical simulation of the adsorption of N acetylneuraminic acid (NANA) on the surface of silica with the participation of the fructose molecule by the method of density functional theory B3LYP, 6-31G $(d, p)$ was done. The influence of the solvent was taken into account in the supermolecular and continuum approximations, and a cluster approach was used for the adsorption complexes. NANA adsorption of the hydrated silica surface was considered as a process of replacement of water molecules on the silica surface by adsorbate molecules.

Two schemes of influence of fructose molecule on NANA adsorption are considered. According to the first scheme, the hydrated NANA molecule interacts with the hydrated silicon-fructose adsorption complex. According to the second scheme, the cluster of hydrated silica interacts with the hydrated NANA-fructose complex.

The energy of intermolecular interaction according to the scheme 1 is $-9.2 \mathrm{~kJ} / \mathrm{mol}$, which is significantly lower compared to the same value with the participation of glucose or sucrose $(-20.5$ and $-86.2 \mathrm{~kJ} / \mathrm{mol})$. Scheme 2 proved to be a thermodynamically unfavorable process, as its energy effect is $+6.9 \mathrm{~kJ} / \mathrm{mol}$, in contrast to similar processes for glucose $(-21.8)$ and sucrose $(-87.7 \mathrm{~kJ} / \mathrm{mol})$. This confirms the experimental fact of the interaction of substances in a mixture of NANA with carbohydrates in relation to the interaction with silica in comparison with the interaction of substances with silica separately

Keywords: N-acetylneuraminic acid, fructose, silica surface, water cluster, adsorption, supermolecular approximation, density functional theory method.
\end{abstract}

Received 28 January 2021; Accepted 15 February 2021.

\section{Introduction}

The surface of highly ultrafine silica (UFS) is covered with hydroxyl groups, which act as adsorption centers for biomolecules and can be replaced by other functional groups. Therefore, UFS is used to create complexes used in medicine, animal husbandry [1-4], etc. In this work [5], a comparison of methods for modifying the surface of silica with saccharides (gasphase method of solvate-stimulated adsorption and liquid-phase impregnation method) was done. The first method in conditions of intensive mixing and regulated atmosphere proved to be more efficient than liquid-phase in such indicators as the degree of surface coverage, consumption of excipients (solvent or solvate), energy and labor intensity and duration of the process.
It is known from literary sources that adsorption from the aqueous phase on the surface of silica glucose, fructose, galactose, mannose [6-8] and NANA [9] is impossible.

Only for $\mathrm{N}$-acetylglucosamine and galactosamine adsorption on UFC is possible, which is explained by the presence of an amino group [10]. During the adsorption of these monosaccharides, a complex $\equiv \mathrm{Si}-\mathrm{OH} \cdots \mathrm{NH}_{2}$ of donor-acceptor nature is formed with a binding energy of $\sim 30 \mathrm{~kJ} / \mathrm{mol}$. The adsorption isotherms of these aminosaccharides, according to the Giles classification, have the form of S3-type. They are characteristic of the case when the energy of interaction between the adsorbed molecules is greater than the energy of interaction between the molecules of the solute and the adsorbent [9]. Self-organization of amino saccharides 
during adsorption is carried out on the surface of the adsorbent due to carbohydrate-carbohydrate interactions. The high degree of binding of aminosaccharide molecules to the surface of nanosilica is confirmed by desorption curves. For $\mathrm{N}$-acetylglucosamine and galactosamine, the desorption from aqueous solution is 28 and $15 \%$, respectively, and from saline -40 and $20 \%$. Thus, the presence of monosaccharides of the group $-\mathrm{NH}_{2}$ in the molecule promotes their adsorption on the surface of UFS [10].

The aim of the study was to investigate the possibility of modifying the surface of silica with fructose for adsorption of NANA using quantum chemical models to assess the energy effect of intermolecular interactions.

\section{Objects and methods of research}

$\alpha$-D-fructopyranose model (Fig. 1, a) was chosen for the fructose molecule, which may exist in aqueous solution [11].

NANA is sialic acid, which is part of glycoproteins and glycolipids (Fig. 1, b) [12].

The silica surface model used a cluster consisting of 18 silicon-oxygen tetrahedra (Fig. 2, a) with a gross composition of $\mathrm{Si}_{18} \mathrm{O}_{48} \mathrm{H}_{24}$, and is proportional to NANA and fructose molecules.
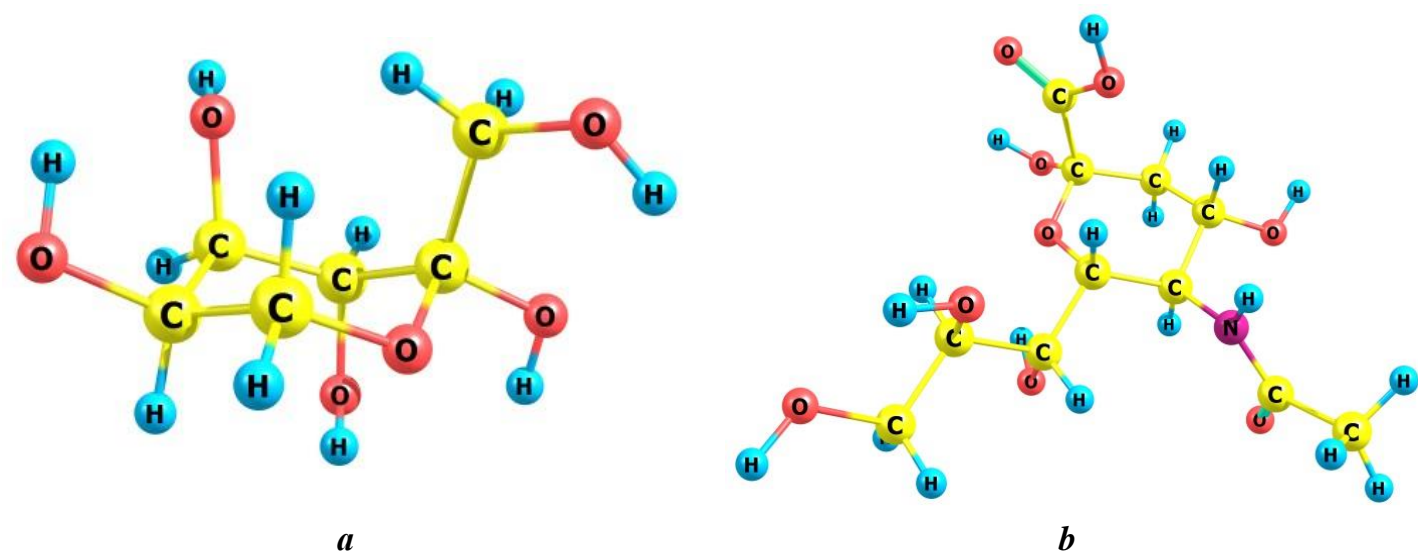

Fig. 1. Molecular models: $a$ - fructose and, $b$-NANA.

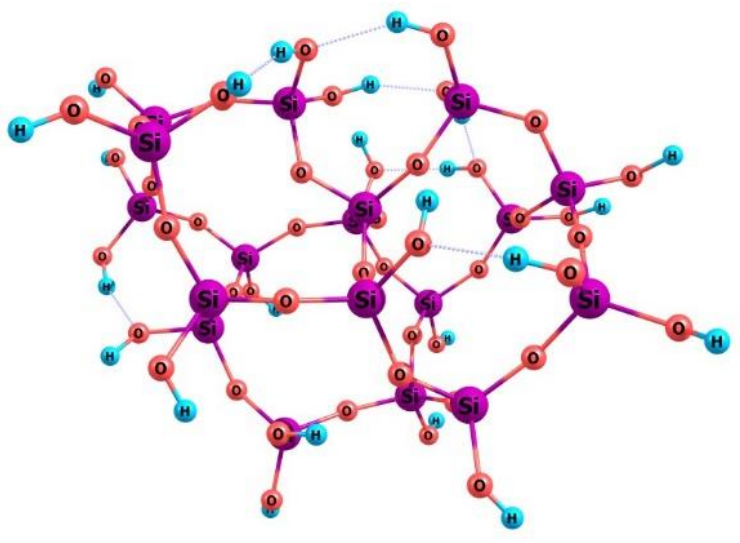

$\boldsymbol{a}$
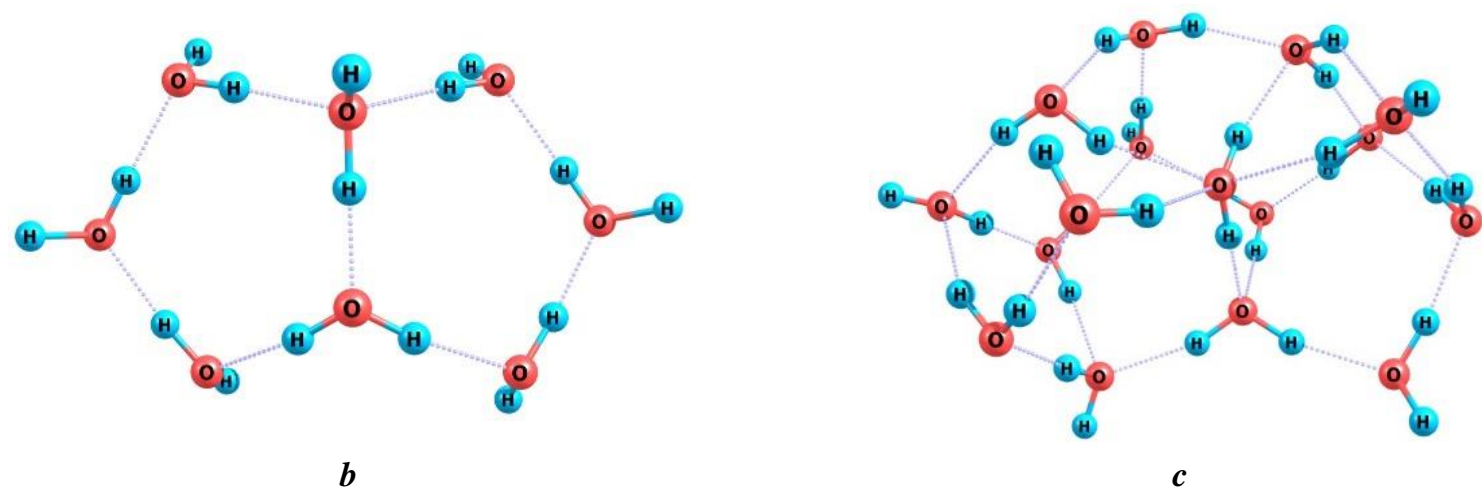

Fig. 2. Equilibrium spatial structure: $a$ - cluster of silica, $b$ - cluster with 8 molecules of water, $c$ - cluster with 16 molecules of water. 


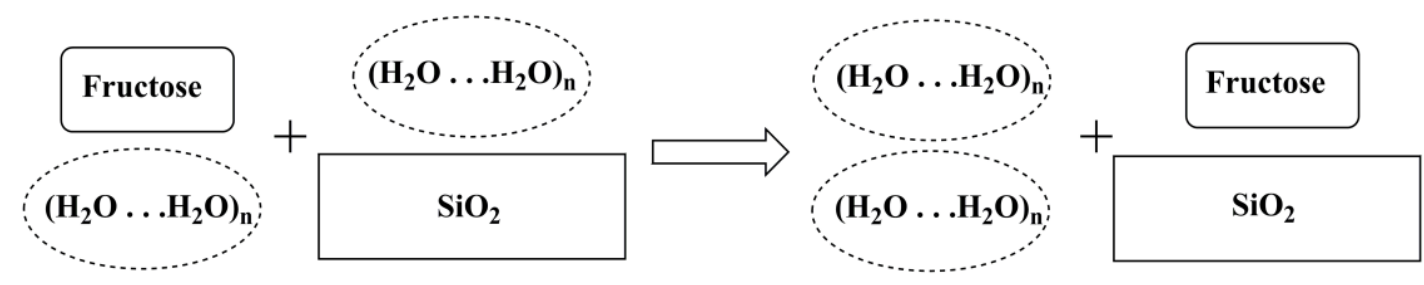

Fig. 3. Scheme of modeling the adsorption of a hydrated fructose molecule on a hydrated surface of silica.

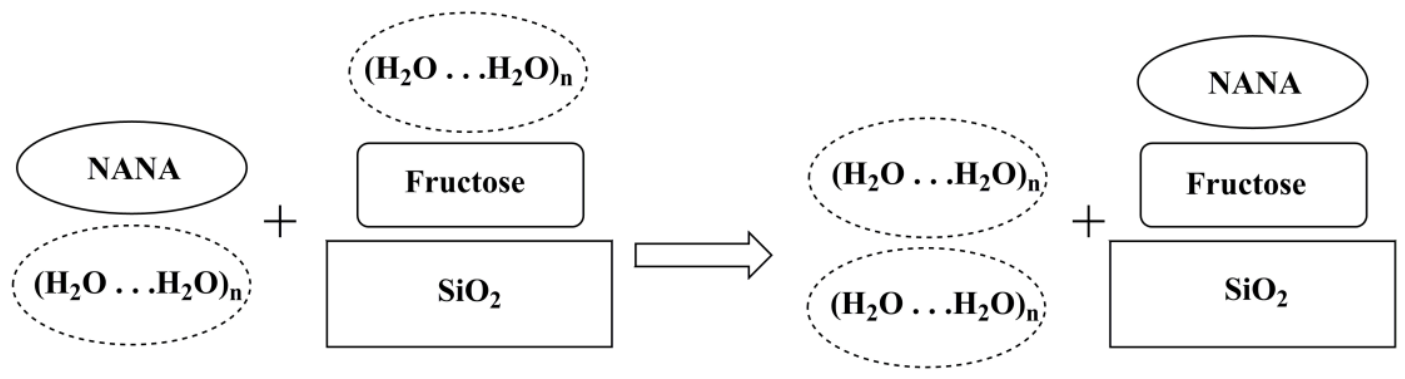

Fig. 4. Scheme 1 of the interaction of the fructose molecule with the surface of silica in aqueous solution.

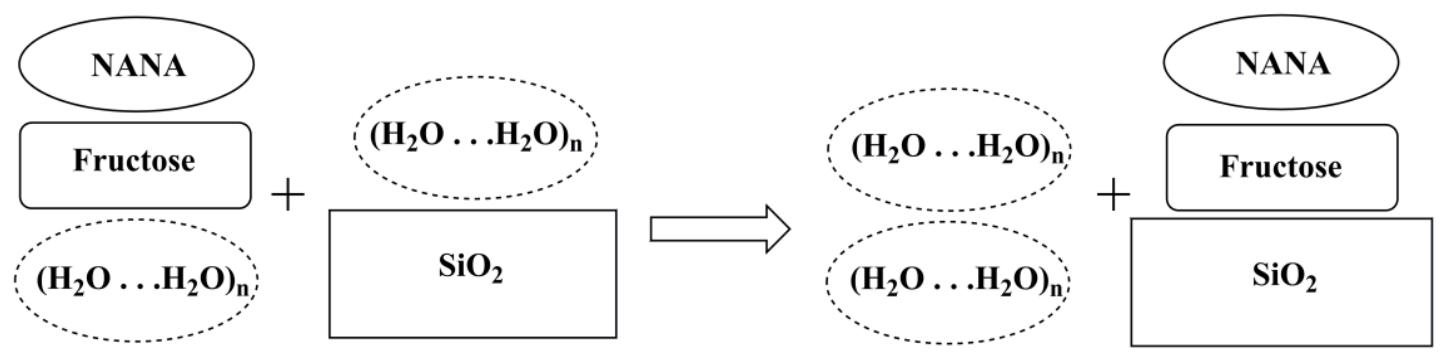

Fig. 5. Scheme 2 - Interaction of the fructose molecule with the surface of silica in aqueous solution.

To take into account the effect of water on the adsorption of NANA on the surface of silica with the participation of carbohydrate molecules, a cluster of 8 water molecules (Fig. 2, b) and the product of its dimerization (Fig. 2, c) were used [17].

The adsorption of a single fructose molecule on the hydrated surface of silica in aqueous solution was considered as a process of replacing water molecules on the surface of silica with a fructose molecule (Fig. 3).

Adsorption energy $\left(\Delta E_{a d s}\right)$ was calculated by the formula:

$$
\begin{gathered}
\Delta E_{a d s}=\left(\left(E_{t o t}\left(16 \cdot \mathrm{H}_{2} \mathrm{O}\right)+E_{t o t}\left(\mathrm{SiO}_{2} \cdots \text { fructose }\right)\right)-\right. \\
-\left(\left(E_{t o t}\left(\text { fructose } \cdots 8 \cdot \mathrm{H}_{2} \mathrm{O}\right)+E_{t o t}\left(\mathrm{SiO}_{2} \cdots 8 \cdot \mathrm{H}_{2} \mathrm{O}\right)\right),\right.
\end{gathered}
$$

where $E_{t o t}\left(16 \cdot \mathrm{H}_{2} \mathrm{O}\right)$ is the total energy of the cluster consisting of 16 molecules of water, $E_{\text {tot }}\left(\mathrm{SiO}_{2} \cdots\right.$ fructose $)$ is the total energy of the adsorption complex of the silica surface is a molecule of detachment, $E_{\text {tot }}$ (fructose $\cdots 8 \cdot \mathrm{H}_{2} \mathrm{O}$ ) is the total the energy of the intermolecular complex of the adsorbate molecule with the water cluster, $E_{t o t}\left(\mathrm{SiO}_{2} \cdots 8 \cdot \mathrm{H}_{2} \mathrm{O}\right)$ is the total energy of the hydrated cluster, which simulates the surface of silica.

To assess the effect of water on the adsorption process in aqueous solution, the hydration energy was calculated $\left(\Delta E_{h y d r}\right)$ as the energy of intermolecular interaction between the water cluster and the hydrated molecule or intermolecular complex (M) according to formula (2):

$\Delta E_{\text {hydr }}=E_{t o t}\left(\mathrm{M} \cdots 8 \cdot \mathrm{H}_{2} \mathrm{O}\right)-\left(E_{t o t}\left(8 \cdot \mathrm{H}_{2} \mathrm{O}\right)+\left(E_{t o t}(\mathrm{M})\right)\right.$,

where $E_{\text {tot }}\left(\mathrm{M} \cdots 8 \cdot \mathrm{H}_{2} \mathrm{O}\right)$ is the total energy of the hydrated molecule or intermolecular complex, $E_{t o t}\left(8 \cdot \mathrm{H}_{2} \mathrm{O}\right)$ is the total energy of the cluster consisting of 8 water molecules, $E_{\text {tot }}(\mathrm{M})$ is the total energy of the studied molecule or intermolecular complex (M).

The adsorption of the molecule of NANA on the surface of silica with the participation of fructose can be considered on the basis of two possible schemes of interaction. According to the first scheme (Fig. 4), the interaction of the NANA molecule occurs with the silicafructose complex. The interaction energy was calculated according to formula (3). The second scheme involves the interaction of a silica cluster with the NANA-fructose complex, where silica binds to the complex through a fructose molecule (Fig. 5).

According to Scheme 1, a water cluster of a hydrated NANA molecule interacts with hydrogen bonds to a similar water cluster, which is bound to an adsorbed fructose molecule on the surface of silica, and the NANA molecule binds to this fructose molecule.

Therefore, the energy of intermolecular interaction according to scheme $1\left(\Delta \mathrm{E}_{\text {Scheme } 1)}\right)$ was calculated by the formula: 
$\Delta E_{\text {schemal }}=\left(E_{\text {tot }}\left(16 \cdot \mathrm{H}_{2} \mathrm{O}\right)+E_{\text {tot }}\left(\mathrm{SiO}_{2}-\right.\right.$ fructose-NANA $\left.)\right)-\left(E\left(\right.\right.$ NANA $\left.\cdots 8 \cdot \mathrm{H}_{2} \mathrm{O}\right)+E_{\text {tot }}\left(\mathrm{SiO}_{2}-\right.$ fructose $\left.\left.-8 \cdot \mathrm{H}_{2} \mathrm{O}\right)\right)$,

where $E_{t o t}\left(\mathrm{SiO}_{2}\right.$-fructose-NANA) - total energy of the adsorption complex silica surface - fructose molecule NANA, $E_{\text {tot }}\left(\mathrm{NANA} \cdots 8 \cdot \mathrm{H}_{2} \mathrm{O}\right)$ - the total energy of the intermolecular complex consisting of a molecule NANA and a cluster of water, $E_{\text {tot }}\left(\mathrm{SiO}_{2}-\right.$ Fructose $\left.-8 \cdot \mathrm{H}_{2} \mathrm{O}\right)$ - the total energy of the intermolecular complex of the silica surface and the hydrated fructose molecule.

The interaction of the hydrated surface of silica with the hydrated intermolecular complex NANA - fructose was calculated according to Scheme 2, which is presented in Fig. 5, according to formula (4):

$$
\Delta E_{\text {schema } 2}=\left(E_{\text {tot }}\left(16 \cdot \mathrm{H}_{2} \mathrm{O}\right)+E_{\text {tot }}\left(\mathrm{SiO}_{2}-\text { fructose-NANA }\right)\right)-\left(\left(E\left(\text { fructose }-\mathrm{NANA}-8 \cdot \mathrm{H}_{2} \mathrm{O}\right)+E_{\text {tot }}\left(\mathrm{SiO}_{2}-8 \cdot \mathrm{H}_{2} \mathrm{O}\right)\right)\right.
$$

where $E_{\text {tot }}\left(\right.$ fructose-NANA- $\left.8 \cdot \mathrm{H}_{2} \mathrm{O}\right)$ - the total energy of the intermolecular complex consisting of a molecule of NANA and a hydrated molecule of fructose.

All quantum chemical calculations were made by the method of density functional theory (DFT) with functional B3LYP [13, 14] and basic set 6-31G (d,p) with the Grimme variance correction D3 $[15,16]$ taken into account within the polarization continuum PCM [17, 18] using the program GAMESS (US) [19].

\section{Results and discussions}

To determine the effect of hydration on the adsorption energy of individual NANA molecules and fructose on the surface of silica, the reaction schematically shown in Fig. 3 was considered. It was assumed that in an aqueous solution, solvent molecules can interact with both the adsorbate molecule and the adsorbent surface, and to account for this interaction, it is necessary to calculate the adsorption energy of the substance in the supermolecular approximation [20]. Water is the solvent and its molecules form hydrogen bonds with both the silica surface and the adsorbate molecule, so adsorption in aqueous solution was considered as a process of exchange of the adsorbate molecule by a cluster of water molecules proportional to the adsorbate molecule (NANA and fructose). The energy effect of the process was calculated by formula

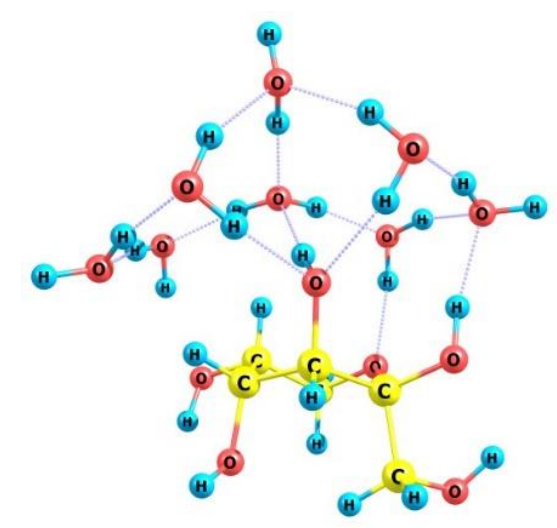

$a$

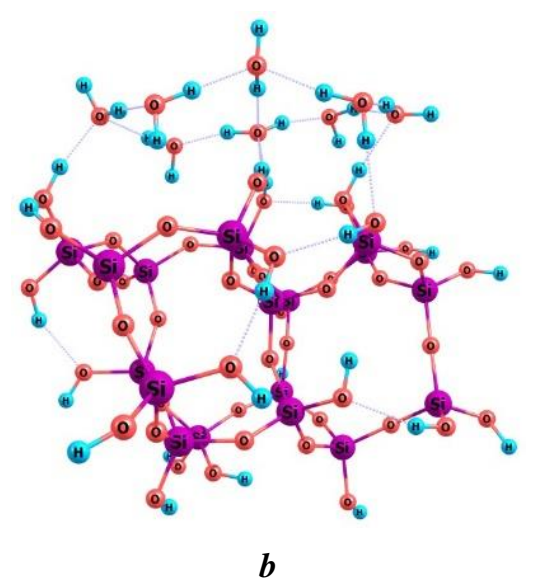

b
(1) where $E_{a d s}$ is defined as the difference of the sums of total energies of the reaction products and starting substances.

The water cluster selected for this study consisted of eight water molecules, which are two condensed fivemembered rings (Fig. 2, b). The size of this cluster of water is proportional to the size of the studied molecules.

This cluster forms hydrogen bonds with the fructose molecule (Fig. 6, a) and the silica cluster (Fig. 6, b) without breaking the condensed five-membered rings, but there is some deformation.

As shown in the works [12, 21, 22], the result of adsorption is intermolecular complexes, which are formed due to the occurrence of intermolecular hydrogen bonds between silanol groups of silica surface and hydroxyl groups of carbohydrates and NANA (Fig. 6, c). Also, according to the scheme shown in Fig. 3, another reaction product is the cluster $16 \cdot \mathrm{H}_{2} \mathrm{O}$, which is formed due to the interaction of two eight-membered clusters (Fig. 2,c).

The calculation results according to equation (1) of adsorption energy for fructose, NANA and carbohydrates are presented in Table. 1. It shows that the energy of adsorption of fructose on the surface of silica in aqueous solution is only $-1.2 \mathrm{~kJ} / \mathrm{mol}$, molecules of NANA $(+0.9 \mathrm{~kJ} / \mathrm{mol})$ and glucose $(+2.7 \mathrm{~kJ} / \mathrm{mol})$ [22]. Therefore, the adsorption of NANA and glucose on the surface of silica is unlikely, since the calculated values are almost

Fig. 6. Hydrated intermolecular complexes consisting of fructose and 8 water molecules $(a)$, a similar silica cluster complex with an eight-membered water cluster $(b)$ [22], and the equilibrium structure of the adsorbed silicafructose complex [12] (c). 
Table 1

Adsorption energy $\left(\Delta \mathrm{E}_{a d s}\right)$ and hydration energy $\left(\Delta E_{h y d r}\right)$ in aqueous solution of test substances (in $\mathrm{kJ} / \mathrm{mol}$ )

\begin{tabular}{|c|c|c|c|}
\hline Fructose & $\begin{array}{c}\text { NANA } \\
{[22]}\end{array}$ & $\begin{array}{c}\text { Glucose } \\
{[22]}\end{array}$ & $\begin{array}{c}\text { Sucrose } \\
{[22]}\end{array}$ \\
\hline \multicolumn{4}{|c|}{ Adsorption energy } \\
\hline-1.2 & +0.9 & +2.7 & -24.5 \\
\hline \multicolumn{4}{|c|}{ Hydration energy } \\
\hline-199.2 & -192.4 & -189.2 & -212.7 \\
\hline
\end{tabular}

zero, in contrast to the negative value of the adsorption energy of the sucrose molecule $(-24.5 \mathrm{~kJ} / \mathrm{mol})$, which is confirmed by experimental data [3, 7].

The hydration energy $\left(\Delta E_{\text {hydr }}\right)$ of fructose calculated according to formula (2) and the one earlier obtained for glucose and sucrose in [22] are presented in Table. 1. It shows that all values of $\Delta E_{h y d r}$ for the considered compounds are negative.

The next stage of the study was to determine the effect of the fructose molecule on NANA adsorption, which can be described by two alternative schemes, according to "scheme 1" (Fig. 4), the hydrated molecule NANA (Fig. 7, a) [22] interacts with the hydrated molecule of fructose, already adsorbed on the surface of silica (Fig. 7, b).

As shown in Fig. 7 in the case of intermolecular complexes, water clusters form hydrogen bonds with the studied molecules without destroying the eight-
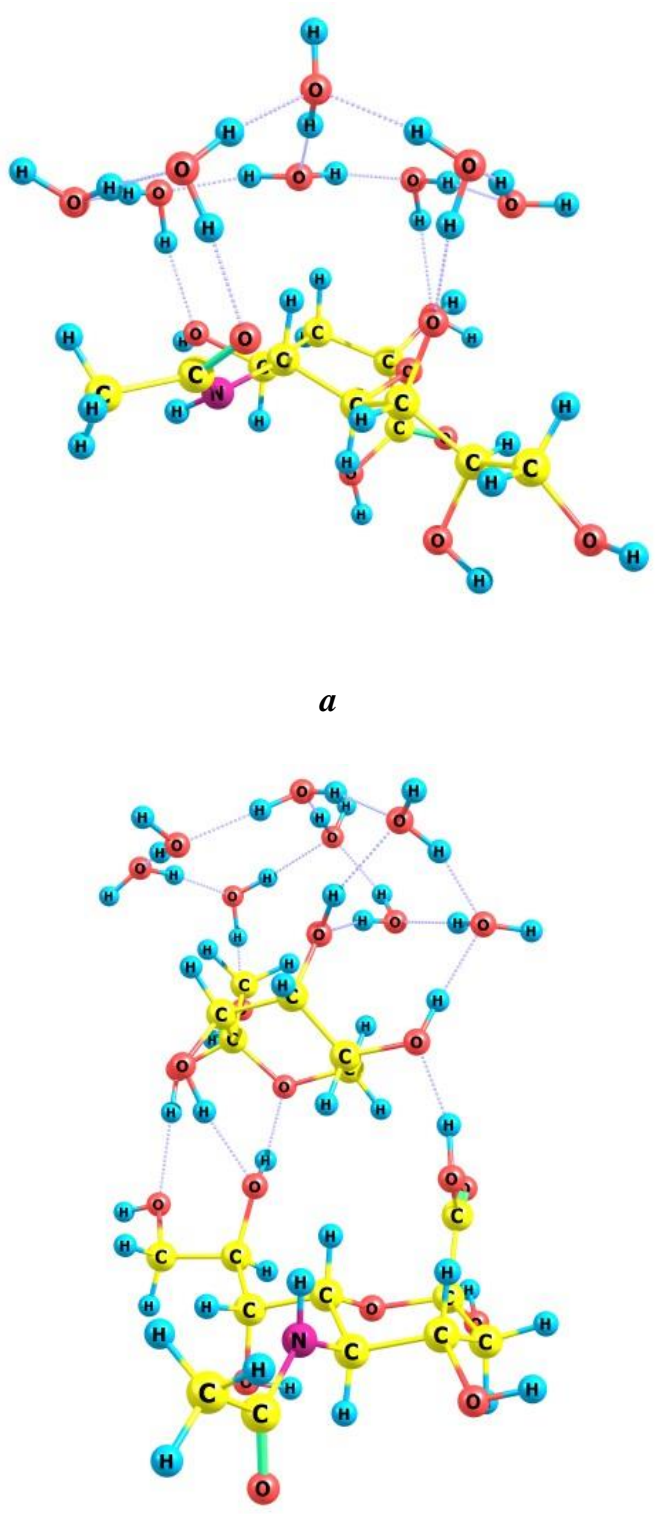

$c$

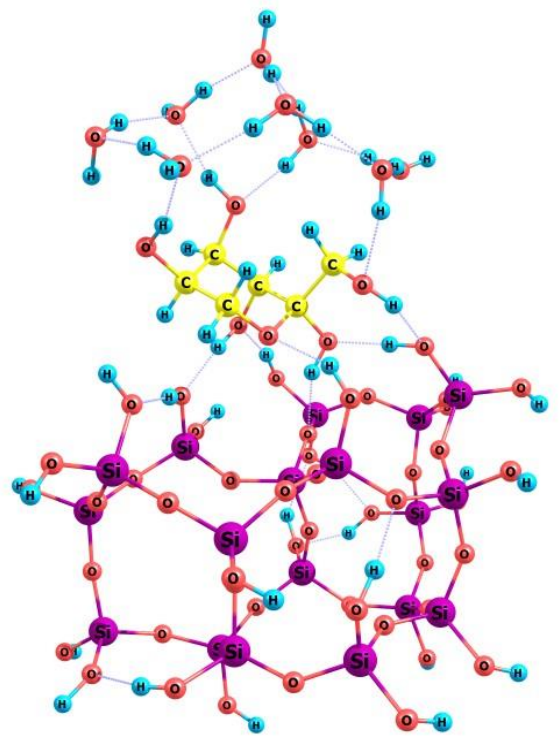

$\boldsymbol{b}$

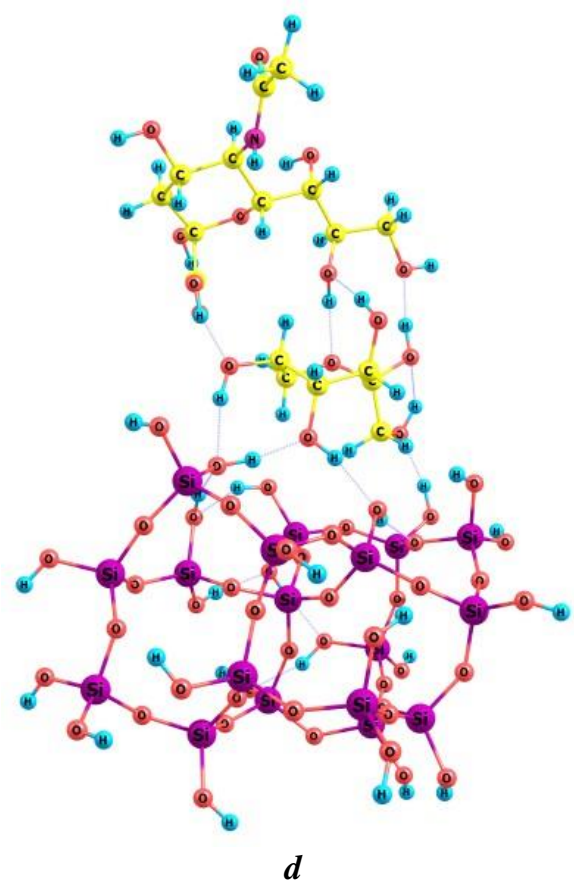

Fig. 7. Equilibrium geometry of intermolecular complexes consisting of $\mathrm{N}$ acetylneuraminic acid and 8 molecules of water [22] (a), silica, fructose and 8 molecules of water $(b)$, of NANA, fructose and 8 molecules of water $(c)$, silica, fructose and NANA $(d)$. 
membered ring (Fig. 2, b), however, there is a significant deformation (Fig. 7, $a, b$ ). As a result of the interaction, a three-component intermolecular complex $\mathrm{SiO}_{2}$-Fructose-NANA is formed (Fig. 7, d). It is similar in structure to the complexes previously considered and described in $[12,21,22]$. Another reaction product is a water cluster (Fig. 2, c), which is formed by the interaction of two smaller water clusters. The energy effects $\left(\Delta E_{\text {schemal }}\right)$ for this system according to formula (3) show (Table 2) that the energy of interaction between NANA and fructose, previously adsorbed on the surface of silica is much higher in absolute value $(-9.2 \mathrm{~kJ} / \mathrm{mol})$, compared with the adsorption energy of the NANA molecule on the surface of silica (Table 1), where this value was only $+0.9 \mathrm{~kJ} / \mathrm{mol}$. However, as can we can see in Table. 2, the value of $\Delta E_{\text {schemal }}$ for fructose is much smaller compared to similar ones calculated earlier for glucose and sucrose [22] (-20.5 and $-86.2 \mathrm{~kJ} / \mathrm{mol}$, respectively).

According to "scheme 2", shown in Fig. 5, the hydrated surface of silica (Fig. 6, b) interacts with the intermolecular hydrated complex from the carbohydrate side of the NANA - carbohydrate complex (Fig. 7, c).

As a result of the reaction according to this scheme (Fig. 5), as well as in the previous one (Fig. 4), threecomponent intermolecular complexes $\mathrm{SiO}_{2}$ - fructose NANA and a cluster consisting of 16 water molecules (Fig. 2,c) are formed (Fig. 7,d)

Analysis of the calculation results by formula (4) shows (Table 2) that, as in the previous case, the interaction energy $\Delta E_{\text {schema2 }}$ of hydrated intermolecular NANA-fructose with hydrated silica surface is positive (see table 1). It is $+6.9 \mathrm{~kJ} / \mathrm{mol}$ in contrast to similar values calculated in [22], which are $21.8 \mathrm{~kJ} / \mathrm{mol}$ for the glucose molecule and $-87.7 \mathrm{~kJ} / \mathrm{mol}$ for sucrose.

When comparing the values of the intermolecular interaction energy, $\Delta E_{\text {schema1 }}$ and $\Delta E_{\text {schema2 }}$ for fructose, we can see that they are significantly different and their energies have different signs (Table 2). However, it should be noted that "scheme 1" at $16.1 \mathrm{~kJ} / \mathrm{mol}$ is thermodynamically more likely than scheme 2 .

As shown in Tab. 2 the common thing for both schemes is that, regardless of the interaction schemes, the highest value of the energy of intermolecular interaction is inherent in the sucrose molecule $(-87.7 \mathrm{~kJ} / \mathrm{mol})$, and the lowest - for the molecule fructose $(-9.2 \mathrm{~kJ} / \mathrm{mol})$. This confirms the previously obtained data [22] that the interaction of the NANA molecule with the surface of silica is thermodynamically more likely to form adsorption complexes in the presence of a sucrose molecule.

\section{Conclusions}

The results of the calculation analysis show that the adsorption of the fructose molecule on the surface of
Table 2

Energy of intermolecular interaction according to "scheme 1" ( $\left.\Delta E_{\text {schemal }}\right)$ and "scheme 2" ( $\left.\Delta E_{\text {schema2 }}\right)$ in aqueous solution for three-component systems

\begin{tabular}{|c|c|c|c|}
\multicolumn{4}{|c|}{$\mathrm{SiO}_{2}-$ carbohydrate - NANA (in kJ/mol) } \\
\hline & Fructose & Glucose [22] & Sucrose [22] \\
\hline Scheme 1 & -9.2 & -20.5 & -86.2 \\
\hline Scheme 2 & +6.9 & -21.8 & -87.7 \\
\hline
\end{tabular}

silica, taking into account hydration, is thermodynamically unlikely, because the adsorption energy is only $-1.2 \mathrm{~kJ} / \mathrm{mol}$, as for the previously calculated glucose adsorption energy [22] $(+2.7 \mathrm{~kJ} / \mathrm{mol})$ as compared with a similar value for sucrose [22] $(24.5 \mathrm{~kJ} / \mathrm{mol})$.

The value of hydration energy $\left(\Delta E_{\text {hydr }}\right)$ for fructose is $-199.2 \mathrm{~kJ} / \mathrm{mol}$, which is less than the largest of the considered, similar values - for the molecule of sucrose $(-212.7 \mathrm{~kJ} / \mathrm{mol})$ [22]. These values correlate with the values adsorption energy and are related to the size of the carbohydrate molecules themselves, which are considered in this paper (fructose $-\mathrm{C}_{6} \mathrm{H}_{12} \mathrm{O}_{6}$, sucrose $\mathrm{C}_{12} \mathrm{H}_{22} \mathrm{O}_{11}$ ).

The energy of the intermolecular interaction of the hydrated NANA molecule with the hydrated silicafructose complex (Scheme 1) is $-9.2 \mathrm{~kJ} / \mathrm{mol}$, which is much lower as compared to the same value with the participation of glucose and sucrose (-20.5 and $-86.2 \mathrm{~kJ} / \mathrm{mol}$ ) [22].

The interaction of the hydrated surface of silica with the hydrated intermolecular complex NANA-fructose (Scheme 2) is a thermodynamically unfavorable process, as its energy effect is $+6.9 \mathrm{~kJ} / \mathrm{mol}$, in contrast to the previously calculated [22] similar processes for glucose $(-21.8 \mathrm{~kJ} / \mathrm{mol})$ and sucrose $(-87.7 \mathrm{~kJ} / \mathrm{mol})$. This confirms the previously established fact that there is a mutual influence of substances in the mixture of NANA with carbohydrates when interacting with silica in comparison with the interaction of test substances with silica separately. Thus the adsorption of NANA is possible if the surface of silica is pre-modified with carbohydrates. The effect is most evident with the participation of the sucrose molecule as confirmed by experimental data [12, $21,22]$.

Ushakova L.M. - junior research;

Demianenko E.M. - Ph.D., senior research;

Terets M.I. - Ph.D., senior researcher;

Lobanov V.V. - Professor, Doctor of chemical sciences;

Kartel N.T. - Academician of the National Academy of Sciences of Ukraine, Professor, Doctor of chemical sciences.

[1] O.O. Chuiko, Silica surface chemistry (IPF UkrINTEI, Kyiv, 2001), Part 1.

[2] L.J. White, G.J. Duffy, Ind. Eng. Chem. 51(3), 232 (1959) (https://doi.org/10.1021/ie51394a019). 
[3] V.E. Nedava, O.I. Smirnova, M.P. Zhuravel', N.P. Galagan, V.I. Bogomaz, A.A. Chuiko, A.P. Sinelnik, V.P. Mikhniuk, Agricultural Biology: Animal Biology (4), 20 (1992).

[4] L. Bondioli, B. Ruozi, D. Belletti, F. Forni, M.A. Vandelli, G. Tosi, Expert opinion on drug delivery 8(7), 921 (2011) (https://doi.org/10.1517/17425247.2011.577061).

[5] L.V. Nosach, Surface 6(21), 83 (2014) (https://surfacezbir.com.ua/index.php/surface/article/view/541).

[6] T.L. Polesia, Ph.D. dissertation, Scientific Research Institute of Pharmacology of the Russian Academy of Medical Sciences (1992).

[7] T.V. Kulyk, Ph.D. dissertation, Institute of Surface Chemistry of National Academy of Sciences of Ukraine (2000).

[8] T.V. Kulyk, B.B Palianytsia, N.P. Galagan, Nanosistemi, Nanomateriali, Nanotehnologii 1(2), 681 (2003).

[9] N.P. Galagan, A.P. Sinelnik, V.I. Bogomaz et al., IV All-Union Conf. "Biological activity of silicon, germanium and tin compounds" (Irkutsk, 1990), p. 67.

[10] G.D. Parfitt and C.H. Rochester, editors, Adsorption from solution at the solid/liquid interface (Academic Press, London, New York, 1983).

[11] M.B. Smith March's Advanced Organic Chemistry: Reactions, Mechanisms, and Structure, 8th ed. (Wiley, 2019).

[12] L.M. Ushakova, E.M. Demianenko, M.I. Terets, V.V. Lobanov, N.T. Kartel, Physics and Technology of Surface 11(3), 420 (2020) (https://doi.org/10.15407/hftp11.03.420).

[13] A.D. Becke, J. Chem. Phys. 98(7), 5648 (1993) (https://doi.org/10.1063/1.464913).

[14] C. Lee, W. Yang, R. G. Parr, Phys. Rev. B 37(2), 785 (1988) (https://doi.org/10.1103/PhysRevB.37.785).

[15] S. Grimme, WIREs Comput. Mol. Sci. 1(2), 211 (2011) (https://doi.org/10.1002/wcms.30).

[16] S. Grimme, S. Ehrlich, L. Goerigk, Journal of Computational Chemistry 32(7), 1456 (2011) (https://doi.org/10.1002/jcc.21759).

[17] M. Cossi, V. Barone, R. Cammi, J. Tomasi, Chem. Phys. Lett. 255(4-6), 327 (1996) (https://doi.org/10.1016/0009-2614(96)00349-1).

[18] J. Tomasi, B. Mennucci, R. Cammi, Chem. Rev. 105(8), 2999 (2005) (https://doi.org/10.1021/cr9904009).

[19] M.W. Schmidt, K.K. Baldridge, J A. Boatz, S.T. Elbert, M.S. Gordon, J.H. Jensen, S. Koseki, N. Matsunaga, K.A. Nguyen, S. Su, T.L. Windus, M. Dupuis, J.A. Montgomery Jr, Journal of Computational Chemistry 14(11), 1347 (1993) (https://doi.org/10.1002/jcc.540141112).

[20] F. Jensen, Introduction to Computational Chemistry, 3th ed. (John Wiley \& Sons, Odense, 2017).

[21] L.M. Ushakova, E.M. Demianenko, M.I. Terets, V.V. Lobanov, N.T. Kartel, Chemistry, Physics and Technology of Surface 11(4), 516 (2020) (https://doi.org/10.15407/hftp11.04.516).

[22] L.M. Ushakova, E.M. Demianenko, M.I. Terets, V.V. Lobanov, N.T. Kartel, Surface 12(27), 36 (2020) (https://doi.org/10.15407/Surface.2020.12.036).

\author{
Л.М. Ушакова, Є.М. Дем’яненко, М.І. Терець, В.В. Лобанов, М.Т. Картель
}

\title{
Взаємодія $\mathrm{N}$-ацетилнейрамінової кислоти з поверхнею кремнезему за участі фруктози у водному розчині
}

\author{
Інститут хімії поверхні ім. О.О. Чуйка, НАН Украӥни, Київ, Украӥна, milushakova@gmail.com
}

\begin{abstract}
Проведено квантовохімічне моделювання адсорбції N-ацетилнейрамінової кислоти (NANA) на поверхні кремнезему за участі молекули фруктози методом теорії функціоналу густини B3LYP, 6-31G(d,p). Вплив розчинника враховувався в супермолекулярному та континуальному наближеннях, для адсорбційних комплексів застосовано кластерний підхід. Адсорбція NANA на гідратованої поверхні кремнезему розглядалась як процес заміщення молекул води на поверхні кремнезему молекулами адсорбату.

Розглянуто дві схеми впливу молекули фруктози на адсорбцію NANA. Згідно першої, гідратована молекула NANA взаємодіє з гідратованим адсорбційним комплексом кремнезем-фруктоза. Згідно другої кластер гідратованого кремнезему взаємодіє з гідратованим комплексом NANA-фруктоза.

Енергія міжмолекулярної взаємодії згідно схеми 1 становить $-9,2$ кДж/моль, що значно нижче в порівнянні $з$ аналогічною величиною за участі глюкози або сахарози (-20,5 і -86,2 кДж/моль). Схема 2 виявилася термодинамічно невигідним процесом, оскільки іiі енергетичний ефект становить $+6,9$ кДж/моль, на відміну від аналогічних процесів для глюкози $(-21,8)$ і сахарози $(-87,7$ кДж/моль). Це підтверджує експериментальний факт взаємного впливу речовин в суміші NANA 3 вуглеводами щодо взаємодії з кремнеземом в порівнянні із взаємодією речовин з кремнеземом окремо.

Ключові слова: $\mathrm{N}$-ацетилнейрамінова кислота, фруктоза, поверхня кремнезему, кластер води, адсорбція, супермолекулярне наближення, метод теорії функціонала густини.
\end{abstract}

